\title{
BISHOP SCORE VERSUS ULTRASONOGRAPHIC TECHNIQUES FOR PREDICTION OF SUCCESSFUL INDUCTION OF LABOR
}

\author{
By
}

\section{Ahmed Al-Sayed Ibrahim Basha, Ashraf Hamdy Mohamed, and Abd El- Moneim Mohamed Zakaria}

Department of Obstetrics and Gynecology, Faculty of Medicine, Al-Azhar University

E-mail: bqashaz@yahoo.com

\begin{abstract}
Background: The process of labor has always been elusive and difficult to grasp till this current era. What is even more elusive knows when it would happen and when to intervene. Throughout the medical literature there has been reliance on clinical examination to predict successful induction. with the advent of ultrasonography this process of relying on subjective clinical data has shifted towards combining both the skills of the examiner with the subjective information from ultrasonography.
\end{abstract}

Objective: Comparing between Bishop Score and transvaginal cervical assessment of prior to induction of labor in prediction of successful.

Patients and methods: This study was conducted at Obstetrics and Gynecology Department, Damanhour Teaching Hospital, from January of 2018 and December of 2018 and included a sample of 200 pregnant women. The mean age of mother in our study was $24 \pm 3.75$ years, the mean BMI was $25.85 \pm 4.33$. The mean gestational age by $\mathrm{U} / \mathrm{S}$ was $38.9 \pm 2$ weeks. The mean bishop score was $7.20 \pm 1.80$, the mean cervical length was $17.54 \pm 4.64$, the mean posterior cervical angle was $116.3 \pm 14.23$.

Results: The results of this study showed that the correlation between labor induction prediction of success using bishop score and ultrasound. The mean bishop score was $7.20 \pm 1.80$, the mean cervical length was $17.54 \pm 4.64$, the mean posterior cervical angle was $116.3 \pm 14.23$. it was found that there was a positive significant correlation between successful induction and pre-induction bishop score, posterior cervical angle and cervical length.

Conclusion: In this study we found that successful induction correlated significantly with the Bishop score and ultrasonographic cervical length \& posterior cervical angle.

Keywords: Sonographic, Bishop Score, Cervical length, Posterior Cervical Angel.

\section{INTRODUCTION}

Induction of labor is considered justified when the benefits of prompt delivery outweigh the consequences of Caesarian Section (CS) (Ara et al., 2018).

Induction of labor is performed in about $20 \%$ of all pregnancies and successful induction is reported to be related to cervical characteristics, or 'ripeness' (Groenevelda et al., 2010).

Today, Bishop score remains the standard method to predict the duration and outcome of induced labor. However, the preinduction 'favorability' of the cervix as assessed by the Bishop score is very subjective and several studies have demonstrated a poor predictive value for the outcome of induction especially in 
women with a low Bishop score (Selhi and Surapaneni, 2010).

In women undergoing induction of labor, pre-induction sonographic assessment of cervical length and posterior cervical angle is superior to the Bishop score in the prediction of outcome of labor (Eid et al., 2017).

In contrast transvaginal ultrasonographic cervical measurement is quantitative and easily reproducible (Anikwe et al., 2020).

In women undergoing induction of labor, significant prediction of the likelihood of vaginal deilvery within 24 hours and the likelihood of ceasarean section are provided by pre-induction cervical length, posterior cervical angle and maternal characteristics. Sonographic parameters were superior to the Bishop score in the prediction of the outcome of induction (Khazardoost et al., 2016).

The aim of this study was to compare between bishop score and ultrasonographic assessment in prediction of successful induction of labor.

\section{PATIENTS AND METHODS}

This study was conducted at Obstetrics and Gynecology Department, Damanhour Teaching Hospital, from January of 2018 and December of 2018, and included 200 pregnant women divided into two equal groups. Informed consents were obtained from all patients in the study.

\section{Inclusion criteria:}

Singleton pregnancies, living foetus, reassuring CTG and cephalic presentation.

\section{Exclusion criteria:}

Multifetal pregnancies, history of previous CS or myomectomy, congenital anomalies, malpresentations, IUFD, any degree of placenta previa or vasa previa, any non-reassuring CTG, active genital herpes or invasive cervical cancer which contraindicate vaginal delivery, extreme low birth weight defined as $<1500 \mathrm{~g}$, previous operations on the cervix (e.g. cautery, cerclage, cervical amputation or conization), and patients already in active labor on admission.

All included women after informed consent were subjected to: written informed consent, complete history taking, complete general examination, abdominal ultrasound to assess fetal wellbeing, placenta, amount of liquor, vaginal examination: to exclude cephalopelvic disproportion, confirm presentation, position and detection of head station and to exclude contraindications of vaginal delivery.

\section{Patients were divided into two equal groups:}

Group 1 patients were subjected to bishops score evaluation via vaginal examination.

Group 2 patients were evaluated via transvaginal ultrasound using Logic C 5Q Premium GE USA Medical Systems (China) vaginal probe $7.5 \mathrm{MHz}$ frequency to assess:

a. The cervical length was measured from internal to external os.

b. Posterior cervical angle was measured in a sagittal plane at the level of the internal os, as the angle between an imaginary line 
traversing the cervical canal and another tangential to the posterior uterine wall at its junction with the internal os. Values were approximated to the nearest degree in the long axis of the cervical canal.

\section{RESULTS}

There was no significant difference between the two studied groups regarding mode of delivery, duration of labor, need for oxytocin augmentation and instrumental delivery (Table 1).

Table (1): Comparison between the two studied groups according to labor events (time to reach $4 \mathrm{~cm}$ cervical dilatation, duration of labor, need for oxytocin augmentation, instrumental delivery by ventouse or forceps) and mode of delivery

\begin{tabular}{|l|c|c|c|}
\hline \multicolumn{1}{|c|}{ Groups } & $\begin{array}{c}\text { Bishop } \\
(\mathbf{n = 1 0 0})\end{array}$ & $\begin{array}{c}\text { Ultrasound } \\
(\mathbf{n = 1 0 0})\end{array}$ & $\mathbf{p}$ \\
\hline $\begin{array}{l}\text { Time to reach 4 cm } \\
\text { cervical dilatation }\end{array}$ & $12 \pm 6$ hours & $10 \pm 5$ hours & 0.326 \\
\hline Duration of labor & $11 \pm 5$ hours & $11 \pm 6$ hours & 0.501 \\
\hline $\begin{array}{l}\text { Need for oxytocin } \\
\text { augmentation }\end{array}$ & 45 & 49 & 0.342 \\
\hline $\begin{array}{l}\text { Instrumental delivery } \\
\text { (forceps, ventouse) }\end{array}$ & 0 & 0 & 0.441 \\
\hline NVD & 71 & 67 & 0.541 \\
\hline CS & 29 & 33 & 0.541 \\
\hline
\end{tabular}

There was a statistically significant positive correlation between Bishop score and labor success. At a bishop score $>7$ with the sensitivity was $78.87 \%$, specificity was $82 \%$., positive predictive value was $91.8 \%$, and negative predictive value was $61.5 \%$ to predict induction success (Figure 1).

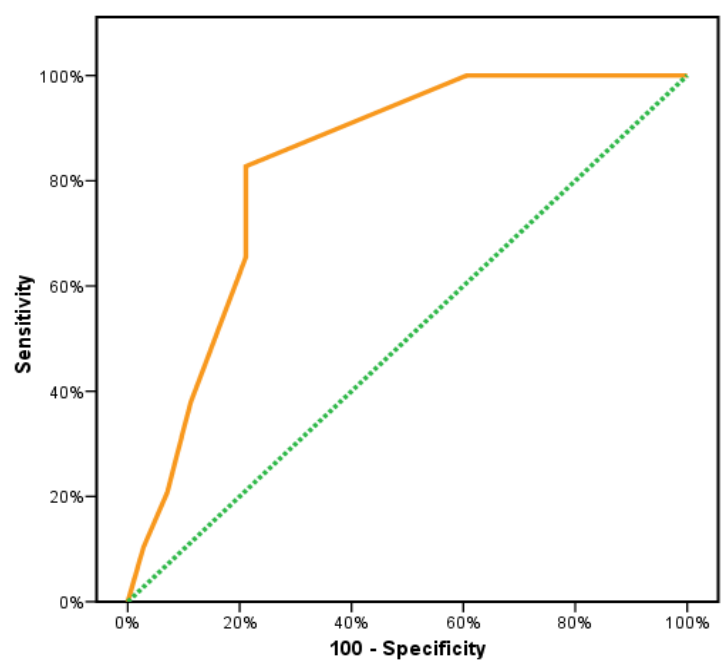

Figure (1): ROC curve for Bishop score to predict NVD cases (vs CS) 
The cervical length ranged between $10.0-29.0 \mathrm{~mm}$. The mean cervical length was $17.54 \pm 4.64 \mathrm{~mm}$. The posterior cervical angle ranged between 90.0 and 147.0. The mean posterior cervical angle was $116.3 \pm 14.23$ (Table 2).

Table (2): Descriptive of the studied cases according to $\mathrm{CX}$ length and posterior cervical angle in ultrasound group $(n=100)$

\begin{tabular}{|l|c|c|c|}
\hline & Min. - Max. & Mean \pm SD. & Median \\
\hline CX length (mm) & $10.0-29.0$ & $17.54 \pm 4.64$ & 17.0 \\
\hline Posterior cervical angle & $90.0-147.0$ & $116.3 \pm 14.23$ & 116.6 \\
\hline
\end{tabular}

There was a statistically significant correlation between cervical length and labor induction success. At a cervical length $\leq 16.7 \mathrm{~mm}$ we were able to predict induction success with a $61.19 \%$ sensitivity, $84.85 \%$ specificity, $89.1 \%$ positive predictive value and $51.9 \%$ negative predictive value (Figure 2).

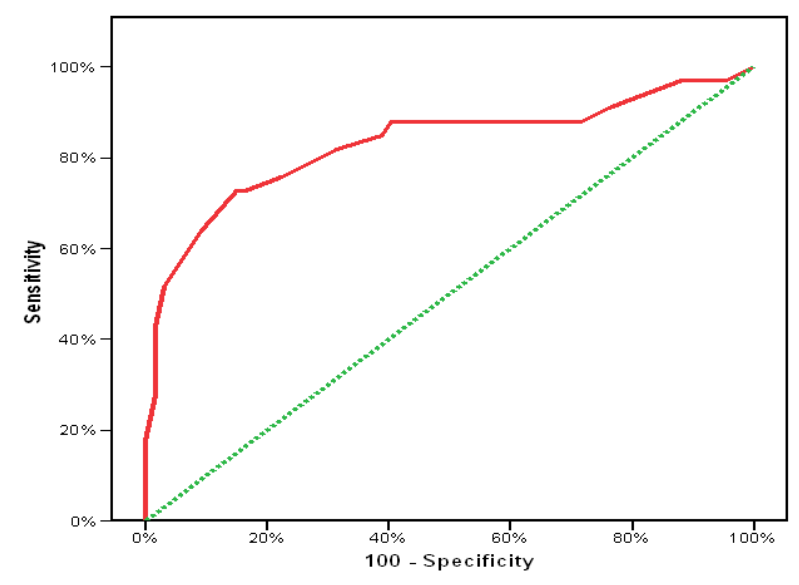

Figure (2): ROC curve for CX length (mm) to predict NVD cases (vs CS)

There was a statistically significant correlation between posterior cervical angle measurement and prediction of successful induction. Posterior cervical angle $>116.8$ had a sensitivity of $55.22 \%$, specificity of $66.67 \%$, positive predictive value of $77.1 \%$ and negative predictive value of $42.3 \%$ to predict induction success (Figure 3).

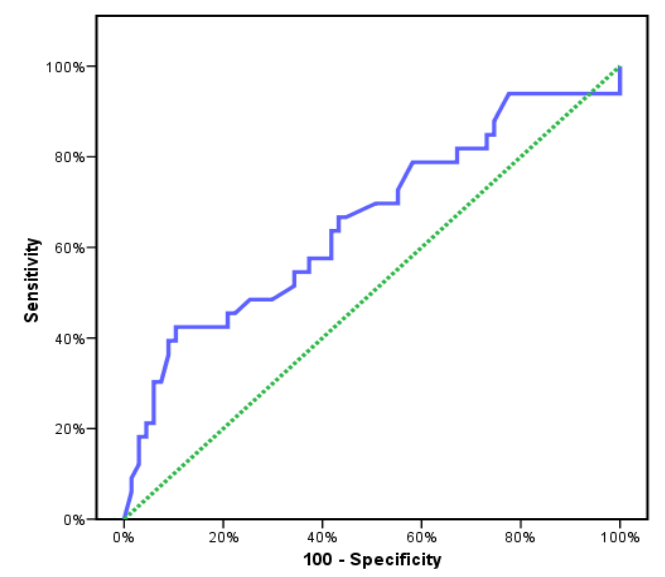

Figure (3): ROC curve for posterior cervical angle to predict NVD cases (vs CS) 
Overall sensitivity, specificity, positive predictive value and negative predictive value of ultrasound were $89.55,63.64$, 83.33, and 75 respectively, while sensitivity, specificity, positive predictive value and negative predictive value of bishop score were $78.87,82.76,91.8$ and 61.5 respectively (Figure 4).

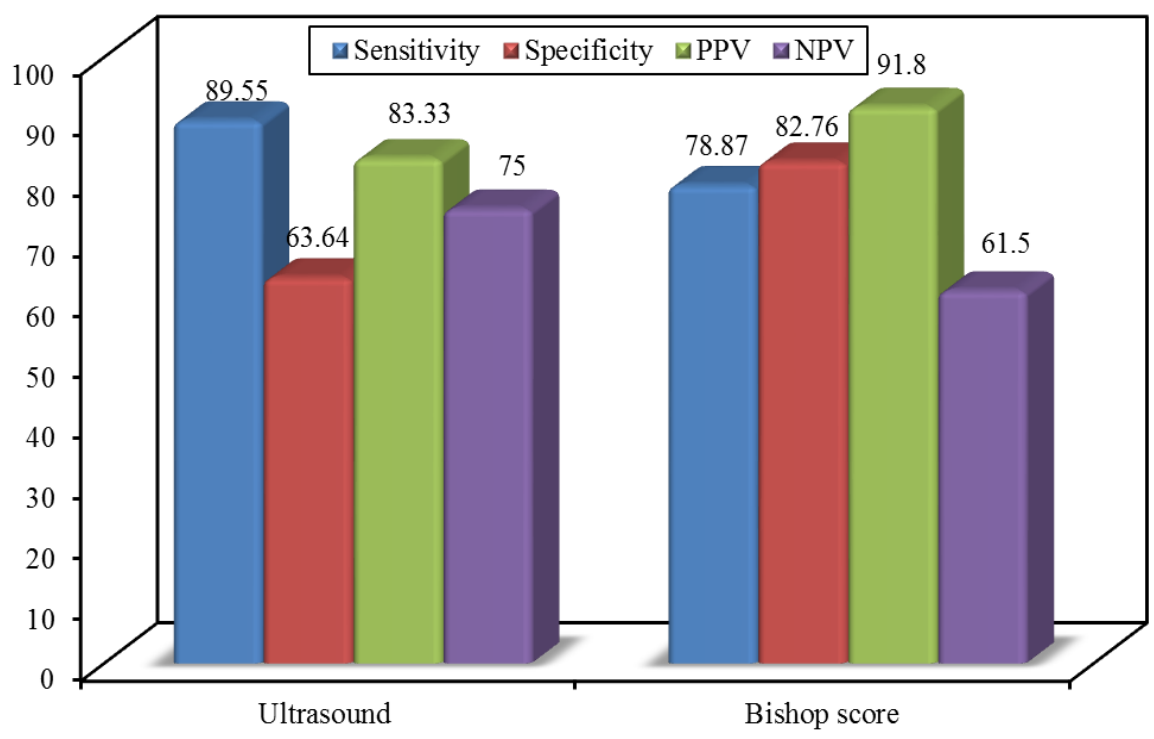

Figure (4): Comparison between ultrasound and bishop score

\section{DISCUSSION}

In our study, $69 \%$ of the participants were delivered vaginally, and $31 \%$ women were delivered by C.S.

Bishop score, ultrasonographic cervical length, and posterior cervical angel provided independent contribution in the prediction of the likelihood of delivering vaginally.

The present study found that successful induction of labor correlated significantly with the Bishop score.

The ultrasonographic cervical length did predict successful induction as the length of the cervical canal signifies the progression from the uneffaced prelabor long cervix to the cervical changes where the cervix is taken up by the process of labor into the formation of birth canal.
The posterior cervical angle rational for induction success prediction is because as the labor progresses with the cervix being taken up into the uterus, the posterior wall of the uterus becomes more aligned with the cervix forming the birth canal losing the natural angle of anteversion between the cervix and the uterus.

Wafa et al. (2018) found that the successful induction correlated significantly with transvaginal ultrasonography measurements of the posterior cervical angle and cervical length and Bishop Score. However Bishop Score appeared to be specific and accurate than the ultrasonographic measurements in prediction of successful vaginal delivery.

Bertossa et al. (2012) conducted a study to evaluate for a score of cesarean 
delivery prediction and found that only the transvaginal ultrasonographic cervical length was associated with the risk of cesarean delivery. Using the different cutoffs of calculated risk of cesarean delivery $(20 \%, 30 \%$, and $40 \%)$, we calculated the sensitivity of $69.6 \%$, $54.3 \%$, and $45.7 \%$, respectively, specificity of $42.0 \%, 58.2 \%$, and $69.2 \%$, respectively, and positive predictive value $19.9 \%, 21.0 \%$, and $23.5 \%$, respectively of the risk score. The area under the receiver operating characteristic curve was 0.59 . There was a poor association between the outcome of labor induction (vaginal delivery or cesarean delivery) and the predicted risk.

Sevrin et al. (2019) evaluated the ultrasound characteristics of the cervix (cervical length, cervical funneling, internal os dilation, the presence or absence of the cervical gland area, and the morphological changes of the cervix as a result of applying fundal pressure) before the onset of labor induction among women with post term pregnancy to identify the possible predictors of failed labor induction. The Bishop score was used for comparison purposes. Three groups were evaluated: successful versus unsuccessful induction, vaginal delivery versus cesarean delivery (excluding cases of acute fetal distress), and vaginal delivery versus cesarean delivery (including cases of AFD). A fourth group including only the primiparous women from the three previous groups was also evaluated. They found based on the studied characteristics and combinations of variables, a cervical length $\geq 3.0 \mathrm{~cm}$ and a $\mathrm{BS} \leq 2$ were the best predictors of induction failure Groenevelda et al. (2010) evaluated transvaginal ultrasonographic measurement of the cervical length versus the Bishop score, prior to induction of labor, in predicting the mode of delivery within four days. By studying women in whom induction of labor was performed at 37-42 weeks of gestation. The agents used for induction were dinoprostone gel on the first 2 days and, if necessary, misoprostol tablets intravaginal on the third or fourth day, the maximum dose of dinoprostone in $24 \mathrm{~h}$ was $3 \mathrm{mg}$ given in two doses. On the third and fourth day a maximum of 75 $\mu \mathrm{g}$ misoprostol in $24 \mathrm{~h}$ could be applied intravaginally in three doses at intervals. Primary outcome criterion was successful vaginal delivery within $96 \mathrm{~h}$. Vaginal delivery was successful in $73 \%$ nulliparous and in $91 \%$ multiparous women, i.e. in $80 \%$ of the total population. The overall rate of cesarean delivery was $17 \%$. Only the Bishop score in nulliparous women showed a significant relationship between this variable and predicting successful labor induction. The best cut-off value for the Bishop score was 3, with a sensitivity of $56.3 \%$ and a specificity of $72.2 \%$. Transvaginal ultrasonographic measurement of cervical length was not a significant independent predictor of vaginal delivery within $96 \mathrm{~h}$. This disagreed with our results as they chose a longer interval (96h) between start of induction and vaginal delivery in order to avoid cesarean delivery as much as possible. Their cesarean delivery rate was $17.3 \%$ compared with $31 \%$ in our study. Long period may be considered extra burden on the participants comparing with our interval $48 \mathrm{~h}$ as prolonged trial of labor leads to maternal exhaustion and longer hospitalization with consequent increased morbidity and financial cost. 
Bastani et al. (2011) studied women with singleton pregnancies undergoing induction of labor at 37-42 weeks. Transvaginal ultrasound was done for all participants prior to induction. The AUC calculated for Bishop Score was 0.39 (95\% confidence interval [CI] 0.3-0.48). The AUC for cervical length measured by ultrasonography was 0.69 (95\% CI $0.6-$ $0.77)$. Testing equality of the ROC curves for these two methods showed the ROC for cervical length to be statistically different from Bishop Score. Agreeing with our results, they found cervical length measured by transvaginal ultrasonography has the potential to replace the traditional Bishop score, provided that such a facility is available when needed.

Keepansereel et al. (2012) studied women undergoing induction of labor induction and were successful in $79.09 \%$. A score was formulated using the parameters having independent association and weighting of individual components was given according to its regression coefficients. The best cut-off point for the Bishop' s score was 5 \&the best cut-off point new score in receiver operating characteristics curve was six with a sensitivity of $95.5 \%$ and specificity of $84.6 \%$..The new score was found to have a better area under the curve than the conventional score. The new score of 6 had a sensitivity of $95.5 \%$, and specificity of $84.6 \%$, and a Bishop's score of 5 with $65.3 \%$ and $80.8 \%$, respectively. In agreement with our study, regarding comparability of bishop score to ultrasonography and adding that a combination of both as practicality, suggest yields a better evaluation of the laboring mother.

\section{CONCLUSION}

Successful induction correlated significantly with the Bishop score and ultrasonographic cervical length and posterior cervical angle.

Conflicts of interest: No conflicts of interest were encountered.

\section{REFERENCES}

1. Anikwe CC, Okorochukwu BC, Uchendu $E$ and Ikeoha CC (2020): The Effect of Ultrasound-Measured Preinduction Cervical Length on Delivery Outcome in a Low-Resource Setting. The Scientific World Journal, 2020: 8273154 .

2. Ara, I., Sultana, R., Solaiman, S. M and Hassain, M. S. (2018): Outcome of Surgical Induction of Labor in a Combined Military Hospital. Bangladesh Medical Research Council Bulletin, 44(1): 52-59.

3. Bastani, P., Hamdi, K., Abasalizadeh, F., Pourmousa, P. and Ghatrehsamani, F. (2011): Transvaginal ultrasonography compared with Bishop score for predicting cesarean section after induction of labor. International Journal of Women's Health, 3: 277-280.

4. Bertossa, P., Mikic, A. N., Stupar, Z. T., Milatovic, S., Boulvain, M., Irion, O. and de Tejada, B. M. (2012): Validity of clinical and ultrasound variables to predict the risk of cesarean delivery after induction of labor. Obstetrics \& Gynecology, 120(1): 53-59.

5. Eid, M., Abdallah, A. and ElHalwagy, A. (2017): Value of transvaginal ultrasonography versus Bishop Score in predicting successful induction of labor. Evidence Based Women's Health Journal, 7(4): 125-130. 
6. Groeneveld, Y. J. B., Bohnen, A. M. and Van Heusden, A. M. (2010): Cervical length measured by transvaginal ultrasonography versus Bishop score to predict successful labour induction in term pregnancies. Facts, views \& vision in ObGyn, 2(3): 187.

7. Keepanasseril, A., Suri, V., Bagga, R. and Aggarwal, N. (2012): A new objective scoring system for the prediction of successful induction of labour. Journal of Obstetrics and Gynaecology, 32(2), 145-147.

8. Selhi, M. and Surapaneni, T. (2010): Pre induction sonographic measurement of cervical length: An adjunct to Bishop Score. Fernandez Hospital Journal of Perinatalogy, 1(2), 20-35.
9. Sevrin, C. E., Martorelli, L. M., Famá, E. A. B., Fernandes, C. E., Sancovski, M. and Oliveira, E. (2019): Ultrasound Evaluation of the Cervix to Predict Failed Labor Induction. Revista Brasileira de Ginecologia e Obstetrícia/RBGO Gynecology and Obstetrics, 41(08): 476484.

10. Wafa, Y. A., Mohamed, N. F. and Abouzeid, M. S. (2018): Comparative Study between 2D and 3D Ultrasound Cervicometry and Digital Assessment of the Cervix before Induction of Labour. Egyptian Journal of Hospital Medicine, 71-75. 
BISHOP SCORE VERSUS ULTRASONOGRAPHIC TECHNIQUES...

\section{مقارنة بين معدل بيشوب والتقييم بالموجات الفوق صوتية

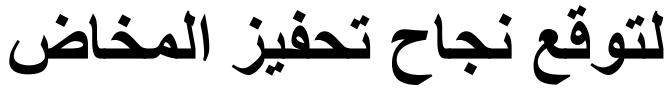

أحمد السيد ابراهيم باشا، عبد المنعم محمد زكريا، أشرف حمدي محمد

قسم التوليل وأمراض النساء، كلية الطب، جامعة الأزهر

خلفية البحث: إن تحفيز الو لادة هو التذخل الطبي لبدء انقباضات الرحم بشكل مصطنع ممـا يؤدي إلى توسع تدريجي لعنق الرحم بالتالي و لادة الجنين.

الهـف من البحث: إستخدام الموجات الفوق صوتية عبر المهبل لقياس طول عنق الرحم وزاويـة عنق الرحم الخلفية وذللك للتنبؤ بالو لادة.

المريضات وطرق البحث: تم إجر اء هذه الدر اسة في قسم أمر اض النسـاء و الو لادة بمستشفى دمنهور التعليمي في الفترة مابين يناير 2018 الى ديسمبر 2018 لمدة اثتى عشر شـر ا والتى تضمنت عينـة من 200 امر أة حامل. وقد تم قياس معامل بيثـوب باستخدام الفحص المهبلي، وتم فحص طول عنق الرحم وز اويه عنق الرحم الخلفيه عن طريق الموجات فوق الصوتية.

نتائج البحث: تم نجاح عملية التحفيز، ووضـت 138 سيدة ولادة طبيعيـة عن طريق المهبل وفثلت عملية التحريض في 62 سيدة، وقد تنبأ كل مت معامل بيشوب وطول عنق الرحم وزاويـة عنق الرحم الخلفية بنجاح تحفيز المخاض بنسب مختلفة.

الاستتناج: قياس طول عنق الرحم وزاويه عنق الرحم الخلفيـة بو اسطة الموجات فوق الصـوتية يبدو أفضل من معامل بيشوب في التنبوء بنجاح الو لادة المهبلية. 